\title{
RANCANG BANGUN APLIKASI PERMAINAN EDUKASI BERBASIS VIRTUAL REALITY MENGGUNAKAN GOOGLE CARDBOARD
}

\author{
Fransiscus Stephen ${ }^{1)}$, Dennis Gunawan ${ }^{2)}$, Seng Hansun ${ }^{3)}$ \\ Program Studi Teknik Informatika, Universitas Multimedia Nusantara \\ Jl. Boulevard Gading Serpong, Scientia Garden, Tangerang, 15811 \\ E-mail : ephenz_267@yahoo.com ${ }^{1)}$,dennis.gunawan@umn.ac.id, hansun@umn.ac.id
}

\begin{abstract}
Technology is one of indifference aspect in human life. There are many fields in human life have been help by technology, especially by the computer technology. Virtual reality is a new way to explore the virtual world. By using it, user can experience new things in the new environment of virtual world. The vastness of virtual world can give many opportunities to learn. "Robot Run" is an edu-game with endless run genre, packaged in virtual reality world that been done in this research. We discussed the way to design and built "Robot Run" edu-game in virtual reality base using Google cardboard as virtual reality tool. The application then be tested to 30 respondents to get insight on the research results. Data analysis results show that the respondents already satisfied with the edu-game application built within the research by $81.37 \%$.
\end{abstract}

\begin{abstract}
Abstrak
Teknologi merupakan salah satu bagian yang tidak dapat dipisahkan dari kehidupan manusia. Berbagai bidang dalam kehidupan manusia telah sangat dibantu dengan keberadaan teknologi, terlebih teknologi komputer. Virtual reality merupakan suatu cara baru untuk menjelajahi dunia virtual. Dengan virtual reality, pengguna seakan-akan masuk ke lingkungan baru dalam dunia virtual. Luasnya dunia virtual dapat memberikan banyak peluang untuk menghasilkan beragam cara untuk belajar. "Robot Run” adalah permainan edukasi dengan genre endless run dalam virtual reality yang dibuat dalam penelitian ini. Penelitian ini membahas mengenai cara merancang dan membangun aplikasi permainan edukasi "Robot Run" berbasis virtual reality menggunakan Google cardboard sebagai alat bantu penerapan virtual reality. Aplikasi telah berhasil dibuat dan diuji ke 30 responden untuk mengetahui tingkat kepuasan responden terhadap aplikasi yang telah dibuat. Hasil analisis data mengatakan bahwa para responsen puas dengan aplikasi yang telah dibuat dengan persentase kepuasan pengguna sebesar $81,37 \%$.
\end{abstract}

Kata kunci: endless run, game edukasi, Google cardboard, Unity, virtual reality

\section{PENDAHULUAN}

Teknologi merupakan salah satu bagian yang tidak dapat dipisahkan dari kehidupan manusia. Teknologi lahir untuk membuat hidup manusia menjadi semakin praktis dan terbantu [1]. Teknologi terus berkembang dan membantu berbagai bidang dalam kehidupan manusia. Salah satu teknologi yang sangat berkembang adalah teknologi komputer. Keberadaan teknologi komputer sangat membantu pekerjaan manusia, seperti menghitung pekerjaan, mengetik sebuah laporan, dan dapat digunakan untuk mengisi waktu luang dengan bermain permainan pada komputer. Kemajuan teknologi komputer sangat pesat sehingga banyak dicari orang yang memiliki kemampuan akan ilmu komputer. Teknik informatika secara khusus merupakan bagian dari ilmu komputer [2]. Menurut salah satu artikel edukasi kompas pada tahun 2014 [3], Teknik informatika merupakan salah satu jurusan perkuliahan yang sangat diminati pada tahun 2014. Berperan sebagai salah satu mahasiswa teknik informatika, terdapat keinginan untuk menyebarluaskan pengetahuan mengenai teknik informatika untuk membantu orang yang memiliki keinginan untuk mengetahui tentang teknik informatika lewat sebuah teknologi. Salah satu bidang kehidupan yang telah ditelaah adalah bidang pendidikan. Menurut Loomans dan Kohlberg [4], cara yang paling efektif dalam kegiatan pembelajaran adalah ketika belajar dikombinasikan dengan unsur yang menyenangkan, seperti dikutip "learning is most effective when it is fun". Permainan 
merupakan sebuah bentuk dari kesenangan, di mana permainan memberikan kita kenikmatan dan kesenangan [5]. Dengan menggabungkan dua pernyataan di atas maka dapat ditarik kesimpulan bahwa cara paling efektif dalam kegiatan pembelajaran adalah ketika belajar dikombinasikan dengan unsur yang menyenangkan yaitu permainan. Maka dari itu, dalam penelitian ini digabungkan teknologi komputer dalam aplikasi permainan ke dalam bidang pendidikan teknik informatika.

Virtual reality adalah real time grafis interaktif dengan model tiga dimensi, dikombinasikan dengan teknologi layar yang dapat memberikan pengalaman pada pengguna seperti masuk ke dalam dunia virtual dan dapat memanipulasi secara langsung [6]. Virtual reality merupakan bentuk pendekatan baru yang memungkinkan pengguna untuk melakukan interaksi dalam lingkungan simulasi komputer. Dengan simulasi komputer, dapat dibentuk lingkungan pada kondisi yang sangat bebas dan beragam. Salah satu pemanfaatan virtual reality adalah dalam dunia game.

Video game adalah segala bentuk software hiburan yang interaktif. Video games sangat populer, khususnya di kalangan remaja dan dewasa muda [7]. Game tidak hanya dibuat untuk kesenangan belaka saja, melainkan dibuat untuk tujuan edukasi. Dalam penelitiannya, Batson dan Feinberg [8] menyatakan bahwa setelah para responden memainkan e-learning game CreditSafe, $84 \%$ siswa sebagai respondennya lebih tertarik untuk mempelajari tentang kartu kredit dan penggunaannya. Dari pernyataan tersebut dapat diketahui bahwa game dapat menjadi salah satu cara untuk memberikan pembelajaran kepada orang lain.

"Endless Run" adalah permainan di mana karakter utama dalam permainan terus menjalankan permainan yang tidak akan berhenti [9]. Semakin lama pemain berhasil memainkan game tersebut menandakan bahwa semakin baik tingkat kemampuan pemain untuk memainkan permainan tersebut. Menurut Dave [10], salah satu faktor penting yang dimiliki oleh game "Endless Run" yang baik adalah faktor "Just One More Run". Faktor "Just One More Run" memiliki arti sebagai faktor yang menghasilkan situasi di mana permain selalu ingin melakukan game tersebut sekali lagi. Hal tersebut dapat dihasilkan dengan membuat design game yang baik, seperti pemberian bonus dalam permainan, terdapat fitur pengembangan kekuatan karakter, dan mengetahui sudah sejauh mana pemain memainkan permainan tersebut dengan membandingkan score yang pemain dapatkan. Faktor "Just One More Run" dalam game "Endless Run" menjadi salah satu alasan mengapa genre "Endless Run" dipilih untuk digunakan dalam penelitian. Dengan faktor "Just One More Run" maka selain meningkatkan keinginan untuk bermain, keinginan untuk belajarpun dapat ikut terbawa. Salah satu contoh game ber-genre "Endless Run" yang sangat terkenal adalah "TempleRun". Di dalam game "Temple Run", pemain harus terus berlari dari monster yang mengejarnya sambil melewati rintangan dengan melompat atau mengambil jalan yang aman. Secara tidak langsung permainan dengan genre "Endless Run" dapat meningkatkan kecepatan refleks karena dengan memainkan game ini, pemain dituntut untuk mengambil keputusan dengan cepat dan tepat sehingga dapat menghindari rintangan yang ada dan tetap dapat melanjutkan permainan.

Luasnya dunia virtual yang ada dapat memberikan banyak peluang untuk menghasilkan beragam cara untuk belajar. Dengan menggabungkan teknologi virtual reality [6] dan metode pengembangan game ber-genre Endless Run yang ada [9], maka dapat dihasilkan suatu cara baru untuk melihat dan mendapatkan pengalaman belajar baru (edugame). Oleh karena itu, dilakukan penelitian mengenai rancang bangun aplikasi permainan edukasi ber-genre "Endless Run" berbasis virtual reality dengan memanfaatkan media google cardboard.

\section{LANDASAN TEORI}

Dalam bab ini akan dijelaskan beberapa landasan teori yang digunakan dalam penelitian, meliputi virtual reality, Google cardboard, game edukasi, dan endless run.

\subsection{Virtual Reality}

Virtual reality adalah real time grafis interaktif dengan model tiga dimensi, dikombinasikan dengan teknologi layar yang dapat memberikan pengalaman pada pengguna seperti masuk ke dalam dunia virtual dan dapat memanipulasi secara langsung [6]. Selain itu, virtual reality adalah bentuk teknologi yang membuat komputer menghasilkan dunia atau lingkungan immersive di mana manusia bisa menjelajah dan dibanyak situasi, berinteraksi [11]. Virtual reality menghasilkan lingkungan yang disimulasikan mirip seperti dunia nyata yang dibuat dengan tujuan untuk menghasilkan pengalaman yang menyamai dengan dunia nyata. Di dalam suatu virtual reality, pengguna dapat menjelajahi dunia virtual tersebut dan 
terkadang juga dapat berinteraksi dengan objek di dalam dunia virtual tersebut.

\subsection{Google Cardboard}

Google cardboard merupakan salah satu temuan dari Google yang dibuat untuk menelusuri virtual reality. Cardboard ini bertujuan untuk mengembangkan alat virtual reality yang dapat terjangkau sehingga dapat membiarkan semua orang untuk menikmati virtual reality secara simpel, menyenangkan, dan natural [12].

\subsection{Game Edukasi}

Game adalah sebuah bentuk dari aktivitas atau olahraga yang dimainkan berdasarkan aturan yang berlaku [13]. Edukasi adalah penambahan pengetahuan dan kemampuan seseorang melalui teknik praktik belajar atau instruksi, dengan tujuan untuk mengingat fakta atau kondisi nyata, dengan cara memberi dorongan terhadap pengarahan diri (self direction), aktif memberikan informasi-informasi atau ide baru [14]. Berdasarkan pernyataan di atas dapat disimpulkan bahwa game edukasi adalah sebuah bentuk dari aktifitas yang dimainkan berdasarkan aturan yang berlaku di mana dengan melakukan aktifitas tersebut seseorang dapat mendapatkan penambahan pengetahuan dan kemampuan. Salah satu arti lain dari game edukasi adalah permainan yang dirancang atau dibuat untuk merangsang daya pikir termasuk meningkatkan konsentrasi dan memecahkan masalah [15]. Game edukasi merupakan salah satu bentuk pendekatan baru yang dinilai dapat memberikan penjelasan mengenai suatu materi lebih menarik dibandingkan dengan pembelajaran dengan cara biasa.

\subsection{Endless Run}

Game "Endless Run" dikategorikan sebagai action game, memiliki desain yang linear tanpa akhir, tanpa pemberhentian dan tidak ada stages atau berubah level [16]. "Endless Run" adalah permainan di mana karakter utama dalam permainan terus menjalankan permainan yang tidak akan berhenti [9].Tujuan dari permainan ini adalah untuk mencapai jarak sejauh yang bisa dicapai sampai karakter dalam permainan bertabrakan dengan halangan yang ada sehingga menyebabkan permainan berakhir. "Endless Run" merupakan salah satu game yang tidak membutuhkan banyak kontrol untuk dapat memainkan game tersebut, terkadang hanya dibutuhkan satu set kontrol untuk memainkan seperti menyentuh layar untuk membuat karakter permainan melakukan suatu aksi sehingga cocok untuk hardware mobile.

\section{PERANCANGAN APLIKASI}

Dalam perancangan yang dilakukan, dibedakan menjadi dua bagian, yakni perancangan struktur game dan perancangan aplikasi secara umum. Perancangan struktur game diawali dengan penentuan dan diskusi mengenai jenis dan tema game yang akan dibangun. Permainan edukasi yang dapat mendidik dipilih dengan topik utama mengenai materi pembelajaran dasar beberapa mata kuliah di Program Studi Teknik Informatika karena bermanfaat dan dapat dikembangkan lebih lanjut pada penelitian selanjutnya. Gambaran lebih mendetail terkait elemen-elemen game yang digunakan dan alur proses game dikembangkan disajikan dalam subbab 3.1 dan 3.2, mengenai Struktur Game dan Perancangan Aplikasi.

\subsection{Struktur Game}

Judul Permainan: Robot Run

Formal Elements

1. Players : Single Player Game

2. Objectives

a. Menyelesaikan kuis yang ada dan mendapatkan kartu informasi.

b. Berlari sejauh mungkin untuk mendapatkan score yang tinggi.

3. Procedures

a. Pilih "Start" untuk memulai permainan

b. Lari selama mungkin dan hindari halangan yang muncul dengan bergerak ke kanan atau ke kiri.

c. Selesaikan rintangan yang muncul dan dapatkan bonus untuk tambahan score.

d. Ketika menyelesaikan 4 buah rintangan maka pemain akan masuk ke area kuis.

e. Ketika masuk ke dalam ruangan selesaikan kuis yang ada dan dapatkan tambahan score dan bonus.

f. Setelah menyelesaikan kuis, pemain akan melanjutkan permainan.

4. Rules

a. Terdapat 2 mode permainan: "Running Game" dan "Quiz Game".

b. Kontrol karakter dengan pergerakan kepala. Di dalam area berlari gerakan kepala ke kanan untuk menggerakkan karakter ke kanan dan gerakan kepala ke kiri untuk menggerakkan karakter ke kiri. Ketika menghadapi kuis, gerakan kamera sesuai dengan pergerakan kepala.

c. Untuk memilih menu yang ada dengan menatap pada box menu yang muncul selama 1 detik. Akan terdapat loading bar yang menandakan sudah berapa lama box menu tersebut ditatap. Loading bar akan di-reset setiap kali fokus objek berpindah. 
d. Kecepatan maksimal karakter berlari adalah 8 unit / detik.

e. Dalam 1 siklus permainan, pemain memiliki 1 poin life.

f. Jika karakter menabrak halangan yang ada maka life akan berkurang 1 poin.

g. Jika pemain tidak dapat menjawab kuis dalam kurun waktu yang ditentukan maka sistem akan menganggap jawaban salah.

h. Jika pemain salah menjawab kuis, halangan akan dihasilkan.

i. Jika pemain menjawab kuis dengan benar, maka bonus akan diberikan kepada pemain.

5. Resources
a. Life
b. Waktu
c. Score
d. Shield
e. Speed

6. Conflict

a. Semakin lama bermain tingkat kesulitan dapat bertambah, yaitu kecepatan karakter berlari bertambah hingga batas tertentu.

b. Di dalam kuis area kesulitan dalam mencari jawaban untuk dapat melanjutkan ke area berikutnya.

7. Boundaries

a. Saat berada dalam running area pergerakan terbatas hanya pada pergerakan ke kanan dan ke kiri untuk karakter permainan.

b. Dalam permainan ini hanya dapat berinteraksi dengan pergerakan kepala. Pergerakan yang lain (tangan dan kaki) tidak dapat menghasilkan interaksi dengan objek di dalam game.

8. Outcome

Endless Run. Semakin lama bermain, maka semakin besar score yang akan didapatkan.

\section{Dramatic Elements}

1. Challenge

a. Menghindari halangan yang akan muncul.

b. Menjawab pertanyaan yang muncul.

2. Play

Balance, Rule-based play.

3. Character

Robot Kyle.

4. Premise

Suatu hari di dalam dunia digital, hiduplah sebuah robot yang bernama Kyle. Kyle suka belajar. Banyak hal telah dipelajari, akan tetapi ada 1 hal yang sangat menarik pikiran Kyle, yaitu pelajaran mengenai Teknik Informatika. Akan tetapi tidak terdapat informasi yang cukup di tempat Kyle berada sekarang. Oleh karena itu, Kyle akan melakukan pertualangan untuk mencari informasi dan belajar mengenai Teknik Informatika.

5. World

Dunia virtual digital. Karakter utama akan berlari di dalam suatu dunia digital. Area berlari akan berada seperti sedang berlari di atas data lurus. Area kuis akan berada seperti di dalam suatu ruangan kecil.

\subsection{Perancangan Aplikasi}

Aplikasi dalam penelitian ini dibuat menggunakan Unity3D versi 4.5.5f1 dengan C\# sebagai bahasa pemrograman utama. Digunakan plugin google cardboard untuk membantu menerapkan sistem virtual reality ke dalam aplikasi yang akan dibuat. Digunakan android device sebagai alat bantu penampil virtual reality pada google cardboard. Oleh karena itu, aplikasi dalam penelitian ini akan diterapkan pada sistem android.

Aplikasi permainan ini merupakan permainan edukasi dengan genre "Endless Run" di mana terdapat 2 buah area sebagai area bermain yang menampilkan rintangan yang berbeda pada masing-masing area. Area pertama merupakan area berlari di mana pemain akan terus berlari ke depan secara otomatis dan akan menghadapi rintangan yang disediakan. Terdapat 2 jenis rintangan yang berbeda pada area berlari, yaitu sekumpulan penghalang yang harus dihindari oleh pemain dan sebuah kuis singkat dengan soal yang akan ditampilkan, dibuat berdasarkan materi dari mata kuliah "Konsep Multimedia" dan "Algoritma Pemrograman" Universitas Multimedia Nusantara. Area kedua merupakan area untuk mengerjakan sebuah kuis dalam suatu ruangan. Cara menjawab kuis tersebut akan dibuat dengan menerapkan sistem pemrograman Scratch. Scratch adalah sebuah bahasa pemrograman visual yang memudahkan untuk membuat interactive art, stories, simulations, dan games - dan membagikan hasil kreasi tersebut secara online [17]. Cara pemrograman pada Scratch yaitu dengan drag and drop tools yang disediakan ke suatu area di mana pengguna dapat menyusun tools yang telah diambil untuk membentuk suatu program. Masing-masing tools yang ada pada Scratch memiliki fungsi yang berbeda-beda. Sistem Scratch diterapkan untuk menghasilkan cara pembelajaran pemrograman secara visual pada permainan yang akan dibuat.

Diagram alur permainan dapat dilihat pada Gambar 1. 


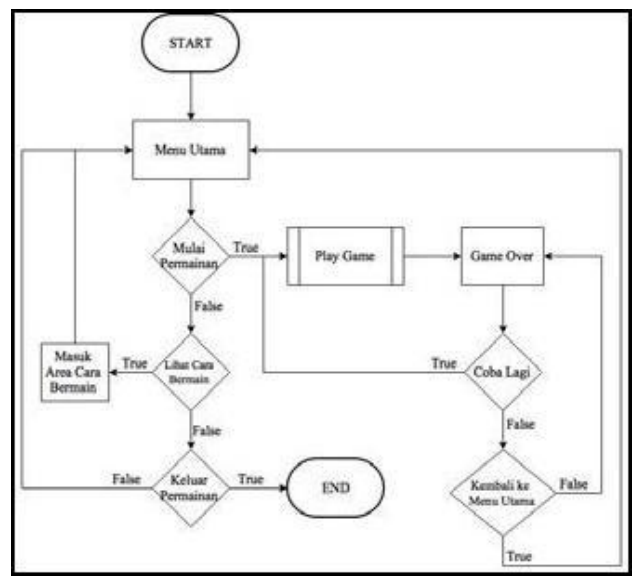

Gambar 1. Flow Chart Sistem Permainan Secara Umum

Gambar 1 merupakan flow chart dari sistem permainan secara umum. Permainan akan dimulai dengan memasuki bagian menu utama. Jika pemain memilih untuk memulai permainan maka permainan akan dimulai. Jika permainan sudah berakhir maka pemain dapat memilih untuk mencoba bermain lagi atau kembali ke menu utama. Pemain yang tidak memilih untuk memulai permainan dapat memilih untuk melihat cara bermain. Jika tidak memilih untuk memulai permainan maupun melihat cara bermain maka pemain dapat memilih untuk keluar permainan.

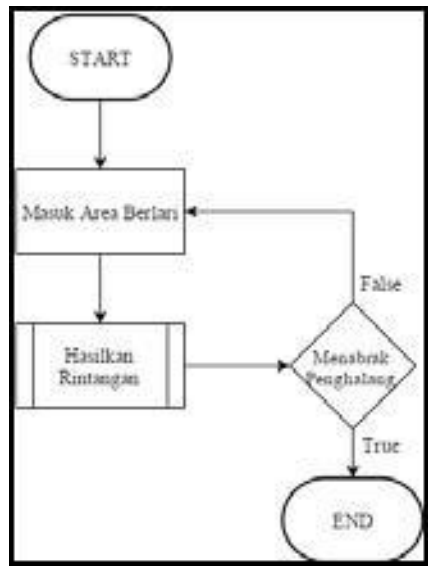

Gambar 2. Flow Chart Proses Detail "Play Game"

Gambar 2 menampilkan flow chart untuk proses detail "Play Game" yang terdapat pada gambar 1, yaitu flow chart sistem permainan secara umum. Proses "Play Game" merupakan proses ketika permainan sedang dimulai. Diawali dengan memasuki area berlari. Kemudian sistem akan menghasilkan rintangan yang dapat berbentuk penghalang, kuis singkat, atau pintu untuk berpindah area menuju area kuis. Jika pemain bertabrakan dengan penghalang maka proses "Play Game" akan berakhir.

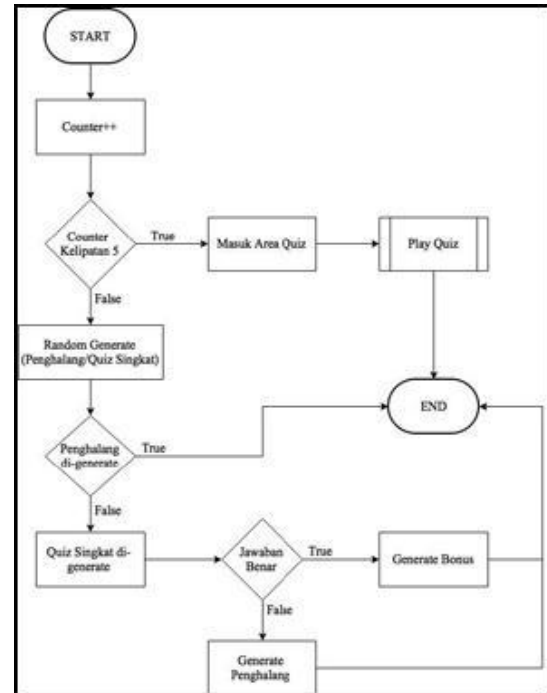

Gambar 3. Flow Chart Proses Detail "Hasilkan Rintangan"

Gambar 3 merupakan flow chart proses detail dari proses "Hasilkan Rintangan" yang terdapat pada gambar 2, yaitu flow chart proses detail "Play Game". Proses "Hasilkan Rintangan" dimulai dengan menambahkan nilai counter yang akan ditambah satu setiap kali proses ini dijalankan. Counter ini digunakan untuk menentukan sistem perpindahan area pada permainan. Setiap kali counter berkelipatan lima, maka area akan berpindah dari area berlari ke area kuis. Di mana setiap area memiliki rintangannya masing -masing. Jika nilai counter bukan kelipatan lima maka sistem akan menghasilkan secara acak jenis rintangan yang akan dihasilkan, antara penghalang atau kuis singkat. Jika rintangan yang dihasilkan adalah penghalang maka proses ini akan berakhir. Jika rintangan yang dihasilkan adalah kuis singkat maka pemain harus memilih jawaban yang tepat. Pada kuis singkat akan disediakan dua buah pilihan jawaban. Kuis singkat tersebut harus diselesaikan sebelum waktu pengerjaan yang disediakan habis, jika tidak maka jawaban akan ditetapkan salah oleh sistem. Jawaban salah akan menyebabkan sistem menghasilkan rintangan tambahan berupa penghalang. Jawaban benar akan menyebabkan sistem menghasilkan objek bonus pada area berlari selanjutnya yang akan dilewati oleh pemain. 


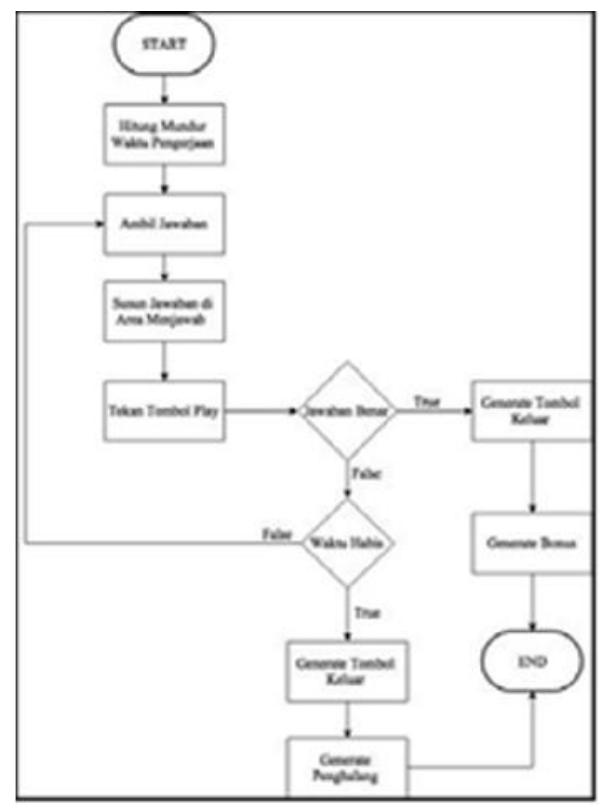

Gambar 4. Flow Chart Proses Detail "Play Quiz”

Gambar 4 menampilkan flow chart proses detail untuk proses "Play Quiz" yang terdapat pada gambar 3, yaitu flow chart proses detail "Hasilkan Rintangan". Proses "Play Quiz" merupakan proses ketika pemain sedang mengerjakan kuis yang berada di area kuis. Proses dimulai dengan menghitung mundur waktu pengerjaan yang disediakan. Kemudian pemain harus mengambil jawaban pada tempat yang tersedia dan menyusun jawaban tersebut untuk menjawab pertanyaan logika pemrograman yang dihasilkan oleh sistem. Untuk mengonfirmasi jawaban yang telah dibuat maka pemain harus melakukan interaksi pada tombol "Play" yang disediakan. Jika jawaban benar maka tombol keluar dan objek bonus akan dihasilkan dan proses ini berakhir. Jika jawaban salah maka sistem akan mengecek jika waktu pengerjaan sudah habis maka tombol keluar dan penghalang akan dihasilkan oleh sistem dan proses akan berakhir. Jika waktu pengerjaan belum habis maka pemain dapat tetap mencoba menjawab pertanyaan yang ada sampai waktu habis.

\section{IMPLEMENTASI DAN UJICOBA}

Aplikasi dibuat pada android device dan untuk membuat aplikasi virtual reality pada aplikasi yang bersangkutan digunakan bantuan dari google cardboard SDK v0.4. Layar aplikasi pada device yang bersangkutan akan terbelah menjadi dua untuk dapat digunakan pada google cardboard.

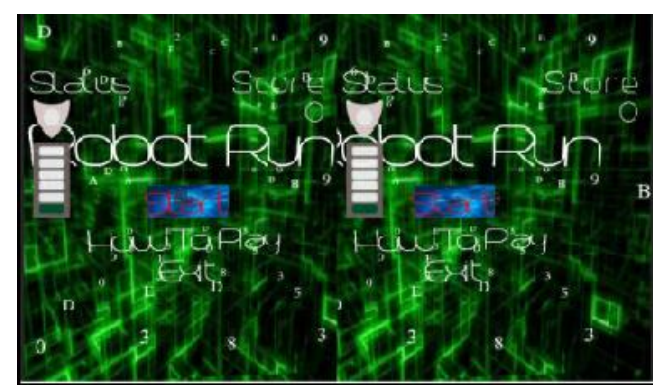

Gambar 5.Antarmuka Menu Utama Aplikasi

Dalam permainan ini terdapat beberapa data source yang dibuat untuk menampung data-data seperti kumpulan pertanyaan dan jawaban untuk kuis singkat dan kumpulan pertanyaan dan jawaban untuk kuis pada area kuis. Data source dibuat dalam teks file yang di-embed ke dalam game object pada Unity. Dengan menggunakan game object tersebut teks akan dibaca dan diambil sesuai kebutuhan. Kumpulan pertanyaan dan jawaban dibuat berdasarkan materi mata kuliah Konsep Multimedia dan Algoritma Pemrograman.

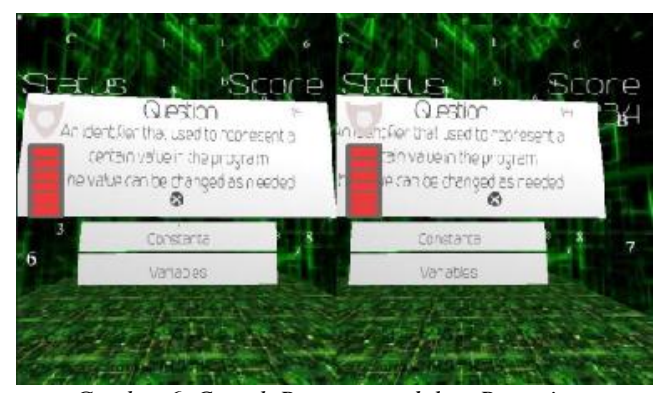

Gambar 6. Contoh Pertanyaan dalam Permainan

Dalam penelitian ini dibutuhkan pengujian aplikasi untuk mengetahui apakah aplikasi yang telah dibuat sesuai dengan kepuasan pengguna. Pengukuran kepuasan pengguna aplikasi dilakukan dengan mengumpulkan data melalui kuesioner. Kuesioner yang digunakan untuk pengumpulan sampel adalah Post-Study System Usability Questionnaire (PSSUQ). PSSUQ adalah 19 buah instrumen yang dibuat dengan tujuan untuk menilai kepuasan yang dirasakan oleh pengguna terhadap sistem yang telah dibuat [18]. Dari 19 soal kuesioner PSSUQ terdapat terdapat aspek penilaian yang dihitung berdasarkan per kategori penilaian, yaitu penilaian aspek Overall untuk pertanyaan 1 sampai 19, penilaian aspek SysUse untuk pertanyaan 1 sampai 8 , penilaian aspek InfoQual untuk pertanyaan 9 sampai 15 dan penilaian aspek InterQual untuk pertanyaan 16 sampai 18 [19]. Data yang terkumpul akan diproses dan dihitung untuk mencari nilai ratarata total sebagai hasil akhir yang didapat dengan cara mencari nilai rata-rata dari setiap kategori, kemudian dihitung persentase dari 
Stephen, dkk., Rancang Bangun Aplikasi Permainan Edukasi Berbasis Virtual Reality Menggunakan..

nilai rata-rata total yang didapat. Skala penilaian yang digunakan adalah skala 5 nilai untuk mengukur kepuasan pengguna dimulai dari 1 untuk sangat tidak puas sampai 5 untuk sangat puas.

Berhasil didapatkan data dari 30 responden dari target sampel untuk usia yang ditentukan. Dari 30 data responden yang berhasil dikumpulkan dapat dihitung penilaian kepuasan pengguna melalui hasil kuesioner yang didapatkan. Tabel 1 adalah tabel perhitungan hasil kuesioner untuk tiap aspek.

Tabel 1. Tabel Hasil Analisis Data

\begin{tabular}{|l|c|}
\hline \multicolumn{1}{|c|}{ Aspek Kategori } & $\begin{array}{c}\text { Persentase Hasil Akhir } \\
\text { (Pembulatan 2 Angka } \\
\text { Dibelakang Koma) }\end{array}$ \\
\hline Overall & $81,37 \%$ \\
\hline System Usage & $77,83 \%$ \\
\hline Information Ouality & $83,14 \%$ \\
\hline Interface Quality & $85,33 \%$ \\
\hline
\end{tabular}

Nilai pada tabel 1 menampilkan persentase dari nilai rata-rata total data kuesioner. Dapat dilihat pada tabel 4.5 , nilai kepuasan yang didapat dari para responden terhadap aplikasi secara keseluruhan (Overall) adalah 81,37\%, untuk kegunaan aplikasi (SysUse) adalah 77,83\%, untuk kualitas informasi (InfoQuaL)adalah $83,14 \%$, dan untuk kualitas dari antarmuka aplikasi (InterQual) adalah 85,33\%. Dari hasil tersebut disimpulkan bahwa tingkat kepuasan pengguna secara keseluruhan adalah $81,37 \%$.

\section{SIMPULAN}

Berdasarkan hasil penelitian, dapat ditarik simpulan bahwa aplikasi permainan edukasi "Endless Run" berbasis virtual reality berhasil dirancang dan dibangun dengan menggunakan smartphone android untuk menjalankan aplikasi dan google cardboard sebagai alat bantu penerapan virtual reality. Dunia virtual reality dalam aplikasi dapat terlihat dan diakses dengan baik saat melakukan percobaan dengan google cardboard. Dengan memanfaatkan gyrometer pada device android yang digunakan, diterapkan pergerakan kepala dengan baik dan lancar untuk pergerakan kamera dan kontrol dalam permainan. Akan tetapi terdapat beberapa kekurangan dalam aplikasi ini, yaitu kenyamanan dalam pemakaian google cardboard tidak terlalu baik karena tidak terdapat bantalan pada bagian dekat mata pemain dan fokus untuk objek 3D dalam permainan kurang baik, sehingga dapat terjadi blur pada beberapa objek saat pemain melihat suatu objek permainan.
Dapat dilihat dari hasil kuesioner dan analisis sampel bahwa para responden dengan kriteria rentang usia 16 - 23 tahun dan memiliki rasa ingin tahu terdapat teknik informasi serta bersedia untuk mengikuti uji coba merasa puas dan mendapatkan pengalaman barupada aplikasi yang telah dibuat dan dicoba dengan persentase kepuasan pengguna sebesar $81,37 \%$.

\section{DAFTAR RUJUKAN}

1. Binus. (2015). PELUANG BESAR UNTUK BERKARIR DI BIDANG TEKNOLOGI. Diakses Juni 6, 2015, dari Binus University: http://binus.ac.id/2015/05/peluang-besaruntuk-berkarir-di-bidang- teknologi/

2. kamuitubeda. (2013). Macam-macam Jurusan Komputer. Diakses 2015, dari kamuitubeda:

http://www.kamuitubeda.com/2013/12/13/m acam-macam-jurusan-komputer/

3. Kompas. (2014). Ilmu Praktis Mendominasi 10 Prodi Paling Diminati dalam SBMPTN 2014. Diakses Juli 16, 2015, dari Kompas.com: http://edukasi.kompas.com/read/2014/07/16 /20143281/Ilmu.Praktis.Mendominasi.10.Pr odi.Paling.Diminati.dalam.SBMPTN.2014

4. Loomans, D., \& Kohlberg, K. (1993). The Laughing Classroom. H.J. Inc.

5. Prensky, M. (2001). Fun, Play and Games: What Makes Games Engaging. Digital Game-Based Learning.

6. Fuch, H., \& Bishop, G. (1992). NSF Invitational Workshop. Research Directions in Virtual Environments, 2.

7. Lenhart, A., Kahne, J., Middaugh, E., Macgill, A., Evans, C., \& Vitak, J. (2008). Exploring the relationship between gaming and civics. Teend, Video Games and Civis.

8. Batson, Laura, \& Susan, F. (2006) . Game Designs that Enhance Motivation and Learning for Teenagers. Journal of Illinois Institue of Technology Electronic, 40.

9. Chong, B. (2015). Endless Runner Games: How to think and design (plus some history). Diakses Juni 15, 2015, dari Gamasutra: http://www.gamasutra.com/blogs/BenChon $\mathrm{g} / 20150112 / 2$

33958/Endless_Runner_Games_How_to_th ink_and_design_plus_some_hi story.php

10. Dave, I. (2013). What Makes Endless Runner Games Successful? Diakses Juni 10, 2015, dari Leviathyn The Gamer's Chronicle:

http://www.leviathyn.com/opinion/2013/04 /24/what-makes-endless-runner-games- 
successful/

11. VPL. (2009). Virtual Reality. Diakses 5 10, 2015, dari Virtual Reality: http://www.vrs.org.uk/

12. Google. (2015, Mei 26). Home: Products > Cardboard. Diakses Juni 4, 2015, dari Google Developers: https://developers.google.com/cardboard/

13. Oxford. (2015). Oxford Dictionaries. Diakses Juli 12, 2015, dari Oxford Dictionaries.

14. Suliha, U. (2002). Pendidikan Kesehatan: Pendidikan Kesehatan, Jakarta: EGC Buku kedokteran.

15. Supriyadinatha, I. M. (2014). Game Edukasi Puzzle Dewa Dewi Hindu dan Tokoh Pewayangan Berbasis Android. Bali: STIKOM Bali.
16. Momoda, J. (2013). Endless Runner Games: Evolution and Future. Game Analysis.

17. MIT. (2003). About Scratch. Diakses 76 , 2015, dari Scratch: https://scratch.mit.edu/about/

18. Lewis, J. R. (2002). Psychometric Evaluation of the PSSUQ Using Data from Five Years of Usability Studies. International Journal of Human-Computer Interaction, 464.

19. eHealth Observatory. (2011). Usabiliy Benchmarking ASQ and PSSUQ. Diakses Juni 5, 2015, dari http://ehealth.uvic.ca/resources/tools/Usabil ityBenchmarking/05a-2011.02.15ASQ_and_PSSUQ_Questionnairesno_supplements-v3.0.pdf 